\title{
The Influence of Leadership and Psychological Empowerment on Performance : An Empirical Study on the Indonesian Seafarers
}

\author{
Rini Nurahaju ${ }^{1 *} \quad$ Seger Handoyo $^{2} \quad$ Andreas Budihardjo $^{3}$ \\ 1.Psychology Faculty, Universitas Hang Tuah, Jl Arif Rahman Hakim 150 Surabaya Indonesia \\ 2.Psychology Faculty, Universitas Airlangga, Jl Airlangga 4-6 Surabaya Indonesia \\ 3.Universitas Prasetya Mulya, Jl RA. Kartini, Cilandak Jakarta Indonesia
}

\begin{abstract}
The purpose of this study is to find out the influence of leadership and psychological empowerment of the Indonesian seafarers on their performance. This study uses a quantitative approach. The respondents in this study were 251 seafarers with a minimum one year's working experience. The technique used to collect data was purposive random sampling. The instruments used for collecting data were adopted from the following instruments : Leadership MLQ-5X Rater (Avolio \& Bass), the Psychological Empowerment Instrument (Spreitzer) and the Performance (Williams \& Anderson and Van Scotter \& Motowidlo). Data was statistically analyzed by using regression and path analysis. The results showed that both leadership and psychological empowerment has a positive influence on the performances.
\end{abstract}

Keywords: Leadership; psychological empowerment; seafarer performance

DOI: $10.7176 /$ RHSS/9-12-05

Publication date: June $30^{\text {th }} 2019$

\section{Introduction}

As many Indonesian seafarers working on national or international company, the quality must be improved so that they meet international standards of competence. Of course this requires a skilled seafarer. To fulfill the requirement of an International seafarer is not an easy task, because it must be qualified for either capability and adequate skills, but also supported by positive character values.

One reason of the occurrence of various accidents at sea is because the seafarer doesn't own fundamental character of the situations and conditions that are dangerous and high-risk work environment. According Desislava and Blanpain, 2010 (in Pratama, 2014) the fundamental characteristics that must be owned by a seafarer associated with monotonous work, life isolated on the ship, socially isolated from family and friends, high stress levels, and prepare himself for the bad weather, marine accidents and other unsafe condition of the vessel, among others, is a tough, self-confidence, discipline, adaptable and independen.

Meanwhile, the Sea General Director of Transportation Ministry (Dirjen Perhubungan Laut Kementerian Perhubungan) did not deny the quality of maritime human resources in Indonesia's needs to be improved (Ikawati, 2014). In other words Indonesian seafareer's performance have to be observed.

Previous research on seafarers' performance is associated with many factors. Study's Chaur (2017) found there were four primary dimensions relating to seafarers' management, (1) work attitude, (2) loyalty, (3) payment and (4) welfare and opportunity. However, these four dimensions were all found a positive effect on the work performance as well. The other study investigate the main factors that contribute to job satisfaction of Chinese seafarer, which factor has a significant bearing on the retention rate in the seafaring profession. The results show that the promotion is the most significant factor in job satisfaction, followed by salary and benefits, working environment and feeling of status ( $\mathrm{Li}, 2014)$. Study of Wu (2006) aims to distinguish the 'new professionalism' from the professionalism of the traditional Chinese seafarers in terms of their value systems, career objectives, and professional standards. The Arslan's study improve the seafarer evaluation during sea period and consequently enhancement of safety and ship management performance to prevent accidents and casualties in maritime transportation by utilizing SETS software (Arslan, 2010).

Performance is the ability to work or something that is achieved or shown accomplishment (Motowidlo et al., 1997; Motowidlo \& Van Scooter, 1994). It was widely agreed that the performance is a multidimensional (Borman \& Motowidlo, 1993; Campbell, Gasser, \& Oswald, 1996 in Befort, 2003). Assessed employee performance should include task performance and non-task performance / contextual performance (Motowidlo et al., 1997; Motowidlo \& Van Scooter, 1994 in Befort, 2003).

According Koopmans (2011) task performance can be defined as the ability (ie competence) someone doing his job duties. Of course, what constitutes the core work tasks can be different from the various of jobs. In this case the task performance criteria of seafarers are vary, for example between the seafarers who worked on the deck officers and engine parts.

Otherwise, contextual performance can be defined as the behavior of employees supporting organizations, social, and psychological in which the technical core must function. Contextual performance refers to the behavior that contribute to the culture and climate of the organization. Contextual Performance itself can be divided into 
two which is interpersonal facilitation behaviors) and Job Dedication.

Interpersonal Facilitation Behavior is interpersonal oriented behaviors that contribute to the of the organization's objective. This is different from the specific work of task performance. Facilitation of interpersonal behavior includes actions that improve morale, encourage collaboration, eliminating performance constraint, or assist a colleague doing the work-oriented activity in their tasks.

Job Dedication is the basic motivation for the performance that encourages people to act with deliberate intention of promoting the best interests of the organizations.

Dedication of work centered on behaviors such as self-discipline to follow the rules, work hard, and take the initiative to solve problems in the workplace. Thus the task performance, interpersonal facilitation behaviors and job dedication became important aspect to be measured in relation to the seafarers performances.

A person's performance is certainly influenced by various factors. These factors can be derived from the own individual's or organization / company where he works. According to the results of recruitment, selection and placement of the company, the seafarers became employees of the seafaring company which is the owner of the vessel. Based on a contract that has been agreed, the seafarers which recruited by the organization must carry out their duties to work on ships that have been determined. The question that arises is the extent to which organizations / seafaring companies play a role in the performance of the seafarers it? According Budiharjo (2013), in order to produce optimal performance, compatibility between environment and organizational culture with organizational dimensions such as structure, technology, human resource strategy should be congruent and professionally managed by a visionary leadership. In a dynamic and competitive environment, the company should be able to move fast, responsive and controlled by leaders who have a far ahead vision or transformational. Based on the statement can be inferred that leadership in the company is very important. The company creates an environment where people can develop self-esteem, enthusiastically participated in the company's life and society. Leadership in the company taking part in which one or more persons share a high motivation and morality but also encourage deteriorating business performance and jeopardize safety. This reinforces the assumption that the leadership in a ship will affect the seafarers performance. In the boat, there was a higher stress, fatigue, work, and lack of sleep. On the other hand the lack of time and there are no conditions for a vacation quality. In this leadership modalities to face new challenges, leaders need to motivate and involve the team, working in difficult conditions, in order to achieve organizational objectives with optimal teamwork. This challenge requires an inspirational and motivational leader that able to change their team members to work more than expected (Delgado, 2012). Leadership can be divided into transformational and transactional leadership.

Transformational leadership approach originally proposed by James MacGregor Burns in 1978. The character of transformational leaders are those that stimulate and inspire followers. The existence of intense competition with seafarers from foreign countries make them to should have the good competence and confident in his ability. The leader must continually provide encouragement, motivation, spirit, self-confidence to the seafarers so that they are powerful in works.

Transactional leadership is 'motivating' subordinates by way of exchanging rewards with the performance of subordinates. The relationship of leadership meant to indicate that the transactional leader stressed in the exchange which has short-term and economic value. Study of transactional leadership style implies an economic exchange process carried out between leaders and subordinates.

Study of Clarke (2013) examine safety for performance seafarers. This shows that both transformational and active transactional leadership styles are important aspects of effective safety leadership. The findings suggest that active transactional leadership is important in ensuring compliance with rules and regulations, whereas transformational leadership is primarily associated with encouraging employee participation in safety. Therefore, in line with the augmentation hypothesis of leadership, a combination of both transformational and transactional styles appeared to be most beneficial for safety.

But the leadership which have impact on performance will not be optimal if not accompanied by psychological empowerment. Surveys have shown that empowerment has a huge impact on management practice because more than $70 \%$ of organizations have implemented some form of empowerment (Lawler, Mohrman and Benson, 2001 in Seibert, 2011).

Psychological empowerment is to build motivation that comes from an employee perceptions about choice in initiating and managing action, has the ability to do a good job, because it can have an impact on the environment, and the meaningfulness of work (Spreitzer, 1995; Thomas \& Velthouse, 1990). On the basis of the work of Thomas and Velthouse (1990), Spreitzer defines psychological empowerment as an intrinsic task motivation that reflect the sense of control in relation to a person's job and active orientation for the person's work role that manifested in four cognitions, which is meaning, self-determination, competence and impact (Seibert , 2011).

Meaning of the occupation or profession becomes important. Meaning is appropriateness or compatibility between the value of an individual with the organization. Research Gregory et al (2010) suggest that individuals who have good compatibility in the organization have an impact on their perception of management practices which in turn affect the behavior and attitude towards work. A seafarer who take pride in their profession will 
positively interpret his work. He knows that his work is important both for personal and organization and even the marine world.

Self-determination is a person's choice about the initiation or regulation from an actions (Deci, Connell, \& Ryan, 1989). Determination is a mental attitude that is characterized by a strong commitment to achieving certain goals despite obstacles and difficulties; a process in decision-making, reaching the conclusion, or ensuring the outcome of each process (Vandenbos, 2008). If employees believe that they were just following orders someone confined to the hierarchy, if they feel a lack of autonomy and freedom, they will also lack a sense of empowerment (Wagner, 1995 in Spreitzer, 1997). A seafarer who have autonomy in the choices of work, then he will also feel empowered.

Competence or self-efficacy, according to Spreitzer (1997) is the belief that a person has the skills and abilities necessary to perform a job or task well (Gist, 1987) and is analogous to one's beliefs, personal mastery, or expectations of the effort-performance (Bandura, 1977 ). Without a sense of confidence in their abilities, individuals will feel inadequate, and they also will lack a sense of empowerment (Conger \& Kanungo, 1988 in Spreitzer, 1997). In other words, the employee believes that he is capable and skilled enough to perform a given task and promote his appearance. Personnel believe that they can use the resources provided by their organization to undertake the responsibilities (Joo, 2010). Duties as a seafarer is a noble task and not just anyone can be a seafarer due to various requirements. This is certainly a plus value for him so he must believe that he is capable.

Impact is the extent to which one can influence the strategic activities, administrative, or operational work unit (Ashforth, 1989 in Spreitzer, 1995). Without a sense of progress toward the goal, the belief that their actions affect the system, employees will not feel empowered (Thomas \& Velthouse, 1990 in Spreitzer, 1997). If seafarers believe their positive actions bring positive impact for themselves, group, organization and even the world then he will always act positively.

Corporate leaders empowers the seafarers by aligning greater purpose. The practice of empowerment or create a sense of power is the root of organizational effectiveness, especially in a period of transition and transformation. It is important to emphasized on the seafarers. In relation to performance, psychologically, employees who are empowered to anticipate problems and act independently in the face of risk or uncertainty, exert influence over the objectives and operating procedures so that they can produce high-quality work, and show perseverance and resourcefulness to face the barriers to work toward a goal (Spreitzer, 1995b, 2008 in Seibert, 2011).

Seafarers who do not have a strong personality and character will have psychological difficulties experience which ultimately also have an impact on performance. For that internal motivation of seafarers should be high. The contributions of work motivation on the performance can not be ignored, even though the individual ability is very good if his motivation is low, its performance will also be low. From this it can be learned that the ability of seafarers together with the psychological aspects such as motivation in the form of empowering (psychological empowerment) will affect the performance itself in doing business in the marine world, or the ship where he does his profession. When people are empowered psychologically, there will be a change in attitude, cognition and behavior that almost certainly will lead to positive changes in the value orientation, enhance the action of patriotism, the ability to delay gratification of desire, increase self-esteem, self-efficacy, self-awareness and psychological wellbeing (Oladipo, 2009).

Dissertation of Solanki about seafarers empowerment show a comprehensive solution of empowering seafarers cognitively in an integrated environment through hybrid learning mode is proposed as a Seafarer Empowerment Model. Based on his research for this study, the author strongly feels that the model will empower the seafarer with appropriate education to foster growth for self, as well as for the seafaring community. After education seafarers form cluster of influence around them and through networking between the clusters, spread positive awareness about seafaring and shipping in society

\section{Methods}

A quantitative approach is used because of the emphasis on the analysis of numerical data (numbers) which processed with statistical method. The variables used are the leadership (X), psychological empowerment (Y) and the seafarer performance $(Z)$. 
Table 1 : Operationalization of Research Variables

\begin{tabular}{llll}
\hline Variable & Indicator & $\begin{array}{l}\text { Measurement } \\
\text { Scale }\end{array}$ & $\begin{array}{l}\text { Measurement } \\
\text { Scale Model }\end{array}$ \\
\hline Leadership (X) & Transformational leadership & Interval & Likert \\
& Transactional leadership & Interval & Likert \\
Psychological & Meaning & Interval & Likert \\
Empowerment (Y) & Self determinant & Interval & Likert \\
& Competent & Interval & Likert \\
& Impact & Interval & Likert \\
Performance (Z) & Task performance behavior & Interval & Likert \\
& Interpersonal facilitation behaviors & Interval & Likert \\
& Job dedication behaviors & Interval & Likert \\
\hline
\end{tabular}

Respondents are seafarers of merchant ships with the total of 251 people. Seafarers which referred to in the context of this study are the officers and have a minimum term of one year. Researchers get a sample of respondents who are training at the Politeknik Pelayaran Surabaya and seafarers who were checked up at RS PHC Surabaya.

Data collection techniques by using three questionnaires such as the scale of the test MLQ 5X- Rater adaptation of Avolio \& Bass (1995) to measure the leadership that has been summarized into 20 items; Psychological Empowerment Instrument (PEI) from Spreitzer (1995.1996) to measure seafarers psychological empowerment total of 11 items and performance scale (Williams and Anderson (1991) and Van Scotter \& Motowidlom (1996) in Tuuli, 2009) a total of 18 items. The assessment forms of questionnaire answers using weighting by three scale interval. The following categories of weights and measurements on respondent.

Table 3 : Weights and Measurement Category

\begin{tabular}{lll}
\hline Description & Ratings \\
\cline { 2 - 3 } & Favorabel & Unfavorabel \\
\hline Strongly Agree & 5 & 1 \\
Agree & 4 & 2 \\
Neutral & 3 & 3 \\
Disagree & 2 & 4 \\
Strongly Disagree & 1 & 5 \\
\hline
\end{tabular}

Table 4 : Data analysis method

\begin{tabular}{lll}
\hline Research Objective & Analysis Method & \\
\cline { 2 - 3 } & Types of Research & Analysis Techniques \\
\hline $\mathrm{T}-1$ & Associative & Regression \\
$\mathrm{T}-2$ & Associative & Regression \\
$\mathrm{T}-3$ & Associative & Path Analysis \\
\hline
\end{tabular}

\section{Result}

Based on the analysis of data, it is obtained the following results:

Descriptive statistics

Table 5 : Descriptive Statistics Results

\begin{tabular}{llll}
\hline Variable & Mean & Standard Deviasi & Number of Subjects \\
\hline Leadership $(\mathrm{X})$ & 3,7454 & 0,49702 & 251 \\
Psychological Empowerment $(\mathrm{Y})$ & 3,9625 & 0,53307 & 251 \\
Performance $(\mathrm{Z})$ & 4,0464 & 0,39756 & 251 \\
\hline
\end{tabular}

In this study the reliability test performed on each of the variables using SPSS, when the value of Cronbach Alpha $>0,600$ then declared unreliable. Results of testing the reliability of all the variables are shown in Table 6

Table 6 : Reliability Test Results

\begin{tabular}{lll}
\hline Variable & Cronbach Alpha & Description \\
\hline Leadership & 0,865 & Very Reliable \\
Psychological empowerment & 0,850 & Very Reliable \\
Performance & 0,898 & Very Reliable \\
\hline
\end{tabular}

Correlation analysis were conducted to determine the relationship between variables. The relationship is significant if the probability value 0.05 greater than or equal to the sig probability value or $(0.05>\mathrm{sig})$. Correlation processing results, shown in Table 7 
Table 7 : Correlation $\mathrm{X}, \mathrm{Y}$ and $\mathrm{Z}$

\begin{tabular}{llll}
\hline Relationship & Correlation & Sig & Nature of Relationship \\
\hline X to Y & 0,373 & 0,000 & Low, unidirectional and significant \\
X to Z & 0,356 & 0,000 & Low, unidirectional and significant \\
Y to Z & 0,594 & 0,000 & Quite strong, unidirectional and significant \\
\hline
\end{tabular}

The steps of path analysis is divided into two paths where the testing is done as a whole and individuals for two structures were also divided to be sub structure 1 and the sub structure 2 . The following is a summary of the influence of the leadership (X), psychological empowerment (Y) simultaneously and significantly to the seafarer performance $(Z)$

Table 8 : Summary of Influence Leadership (X), Psychological Empowerment (Y) Against Seafarers Performance $(Z)$

\begin{tabular}{lllll}
\hline Variable & Coefficient & Effect & & Total \\
\cline { 3 - 5 } & & Direct & Indirect & 0,373 \\
\hline X to Y & 0,373 & 0,373 & & 0,356 \\
X to Z & 0,157 & 0,157 & $0,373 \times 0,536=0,199$ & 0,536 \\
Y to Z & 0,536 & 0,536 & & 0,927 \\
$\varepsilon$ 1 & 0,927 & & & 0,791 \\
$\varepsilon 2$ & 0,791 & & & \\
\hline
\end{tabular}

Based on the overall results of causal influence on leadership (X), the seafarer psychological empowerment $(\mathrm{Y})$ and their impact on the seafarers performance $(\mathrm{Z})$, the application of the leadership (X) to the seafarer psychological empowerment (Y) by $(0373)^{2}$ or $13,9 \%$. And the remaining $86,1 \%$ of psychological empowerment value is influenced by other variables outside the research. The implementation of leadership on seafaring company (X) directly affects the seafarer performance $(Z)$ of $(0,157)^{2}$ or accounted for $2.46 \%$ and the remaining $97.54 \%$ is the value of the seafarer performance influenced by other variables outside of this study. The implementation of leadership (X) indirectly affect the performance of seafarers $(Z)$ of $(0.199)^{2}$ or accounted for $3.96 \%$. The implementation of leadership $(\mathrm{X})$ on the seafarer performance $(\mathrm{Z})$ through psychological empowerment $(\mathrm{Y})$ is equal to $(0.356)^{2}$ or accounted for $12.67 \%$. Application of psychological empowerment $(Y)$ affect the seafarer performance $(Z)$ of $(0.536)^{2}$ or accounted for $28.57 \%$ and the remaining $71.28 \%$ is the value of the seafarer performance influenced by other variables outside of this study. The framework structure of the complete causal relationship between $\mathrm{X}, \mathrm{Y}$ and $\mathrm{Z}$ are as follows

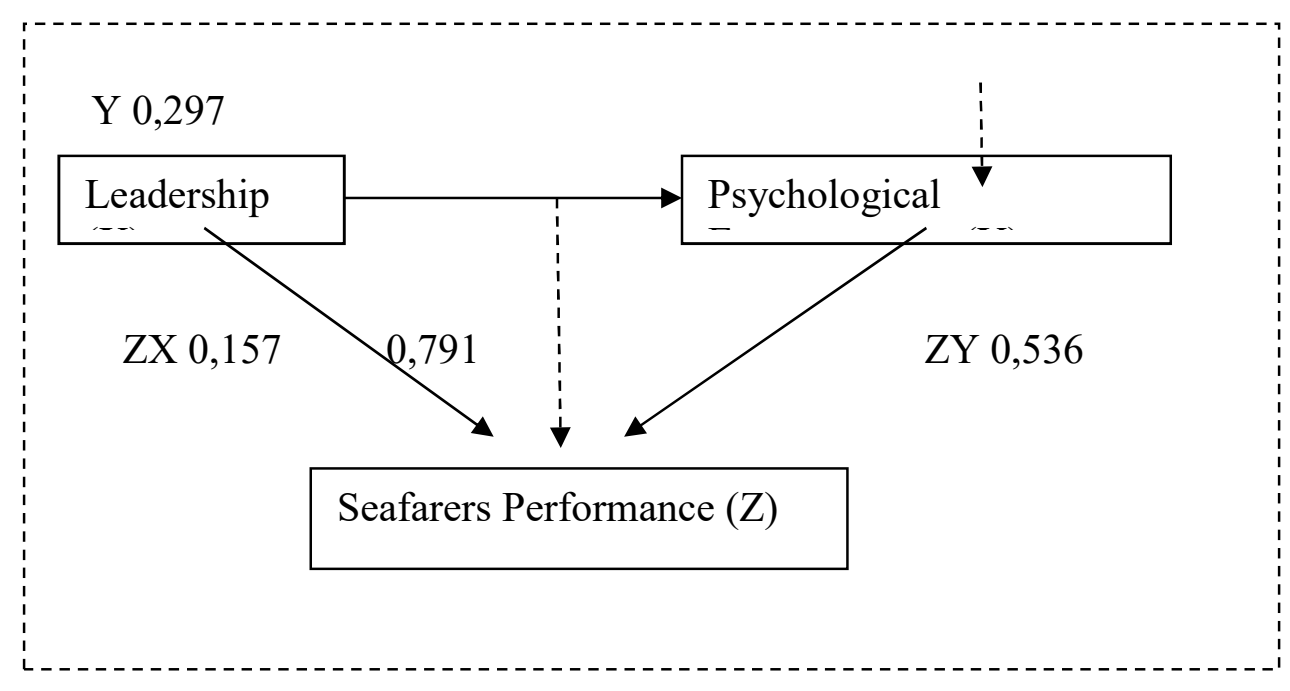

\section{Discussion}

The results showed that the leadership has a positive and significant effect on the level of seafarers psychological empowerment. This means that the level of seafarer psychological empowerment explained by the leadership where leadership is described in this study involves transformational leadership and transactional leadership. The magnitude of the effect of the leadership of the seafaring company toward psychological empowerment is $13.9 \%$. Therefore, to optimize the psychological empowerment, seafaring companies need to pay attention to leadership. The monotonous atmosphere in the vessel can cause fatigue, more work, lack of sleep and many other causes that lead to higher stress. Leaders needed to motivate and involve the team, working in difficult conditions, in order to achieve organizational objectives with optimal teamwork. This challenge requires an inspirational and motivational leader which able to change their team members to work more than expectations (Delgado, 2012). 
According to Bass (Yukl 2010), transformational leadership is a leadership that change and motivate followers by making them more aware of the importance of the task, to persuade them to prioritize the interests of the team or organization rather than personal interests and activating their needs higher. This is according to research Seibert (2011) that the leadership associated with psychological empowerment. Spreitzer (2008) found that a support, trusting relationship with the person leadership is important contextual antecedents of psychological empowerment. Liden, Sparrowe \& Wayne, 1997; Yukl 2010 found the result that the positive form of leadership improve employee perceptions of psychological empowerment because of the leaders important role to shape his employee work experience. Likewise, Ozaralli research (2003) suggest that the transformational leadership contributes to their predictions of empowerment on subordinates. Transformational leaders lead their team members experience the empowerment. The more they have empowerment the more effective the team. Delgado (2012) examined the seafarer transformational leadership with transformational measurement tools MLQ - 5X by Bass and Avolio. His writing aims to analyze and understand the characteristics of leadership and seafarer life better. The findings indicate that the seafarers have a group characteristics associated with of their leaders. They face a very difficult challenge with multinational crews and work under high pressure, fatigue, stress, lack of sleep, social isolation, and excess workload. This situation is a negative influence on their leadership, especially communication and motivational aspects, which can lead to serious consequences, and often lead to conflict in the ship, which is difficult to resolve. It has been proven that transformational leadership explains between $45 \%$ to $60 \%$ of the results of successful organizations, and many studies have shown how good leadership training can help to improve results (Delgado, 2012)

The results showed that seafarers psychological empowerment have positive and significant influence on seafarers performance. Means, the level of seafarer performance is explained by seafarer psychological empowerment, where the influence of psychological empowerment on the performance is $2.46 \%$. Therefore, to optimize the seafarer performance on seafaring companies, there is a need to pay attention on seafarers psychological empowerment. This finding is consistent with the statement put forward by Thomas \& Velthouse (1990) who argued when employees are empowered, they will find work assignments more attractive and therefore more motivated to do their job properly. These results correspond well with studies by Tuuli \& Rowlinson (2009) that empowered employees demonstrate positive performance behavior. Gregory (2010); Avolio, et al, (2004); Seibert, 2004 in Bordin and Bartram (2007); Hechanova (2006) also proved that psychological empowerment proven impact performance. Seibert (2011) writes that psychological empowerment is related not only to the work attitude but also a positive form of performance because psychological orientation more active empower employees as a result of their work. Indradevi research (2012) proved that the performance is predicted by psychological empowerment by $79 \%$, and among the four components of psychological empowerment, meaning become the most important component followed by impact, self-determinant and competence.

An assumption of the theory of empowerment is that the individual is empowered to do better than the relatively less empowered (Thomas and Veltheous, 1990). It is consistent, with the view that employees generally have more complete knowledge about their job information rather than top managers and therefore better positioned to planning and schedule their work and to identify and resolve obstacles that hinder their performance (Cooke, 1994). Thomas and Veltheous, 1990) found when an individual feels empowered then proactive behavior such as flexibility, resilience and persistence occur. Thus when individuals who feel that their work is meaningful and that by completing their work responsibilities affect others inside and outside the organization will motivated to do better (Liden et al, 2000). Individuals who think they have the necessary skills and can choose how to do their jobs also outperformed their comrades who did not. Indeed, the influence of competence and self-efficacy on performance is big.

Simultaneously, the leadership and seafarers psychological empowerment have positive and significant effect on the seafarer performance by $43 \%$. The remaining $57 \%$ is equal to the influence of the other factors.

This is consistent with research Seibert et al., 2004 (in Indradevi, 2012) which surveyed 375 employees in one division of a Fortune 100 manufacturer of high-tech office and printing equipment located in the northeastern United States. This study identified a strong positive relationship between empowerment climate and psychological empowerment. There is little significance in terms of psychological empowerment and individual performance but no significance between empowerment climate and job performance. The study concluded that psychological empowerment should be seen as a theory of intrinsic motivation and not as a comprehensive theory of performance. Indradevi (2012) have identified a strong relationship between employee psychological empowerment and performance and job satisfaction. Research Baek-Kyoo (Brian) Jooa about the research Liden, Wayne \& Sparrow (2000) emphasizes that employees empowerment, psychologically can lead to increased job satisfaction, organizational commitment, and job performance. Meaning and self-determination, the two components of psychological empowerment has proven to have a small relationship but statistically significant with job performance (Fried \& Ferris, 1987; Humphrey et al, 2007) as described by the theory of job characteristics (Hackman \& Oldham, 1980 in Seibert 2011 ). Empirical studies have shown that competence (self-efficacy) and impact improve performance by increasing duties and persistence (Bandura \& Locke, 2003; Stajkovic \& Luthans, 
1998). Research Morgan (2009) also showed that empowered employees showed positive performance behavior. Written that psychological empowerment clearly emerged as a valuable way for organizations to look for improved performance. Referring to the discussion, is expected psychological empowerment to be positivey effect the job performancs.

According to Spreitzer (1995), employee empowerment raises some significant consequences in the form of effective and innovative behavior. At the managerial level, empowering employees are able to contribute significantly. Empowered managers see himself competent and able to influence the work and the work environment in a meaningful way. They are also more proactive in carrying out job responsibilities, for example in anticipating problems and acting independently, so that the work could be carried out effectively. In addition, the empowerment will be able to improve concentration, initiative and flexibility, as to encourage the effectiveness of work of a manager. At the employee level, if they are empowered, they will have the confidence that they are capable of doing the work themselves and have an influence on the basis of the results of such work, so they tend to be more creative. They do not feel bound by the regulations or technical aspects of the job. Confidence in the ability to perform tasks will encourage employees to be more innovative and expect him to succeed.

Spreitzer (2008) concluded, based on the review, that a support, trusting relationship with the person leadership is important contextual antecedents of psychological empowerment. Expected positive form of leadership increases employee perception of psychological empowerment as an leaders important role for the formation of subordinate working experience (Liden, Sparrowe, \& Wayne, 1997; Yukl, 2010).

Application of psychological empowerment has now been proven to be better in calming the hearts and minds of employees and improve performance. However, by demonstrating that employees are empow ered showed positive performance behavior, psychological empowerment clearly emerged as a valuable way for organizations to improve performance.

Therefore, to optimize the seafarer performance, companies must pay attention to its leadership by implementing the right leadership because doing so will make the seafarers feel motivated thus create optimal psychological empowerment that will be followed with high performanc

\section{Conclusion}

Based on the analysis of research data to answer the problem formulations, it can be drawn is the leadership have a significant influence on the psychological empowerment seafarers of $13.9 \%$. Leadership have a significant effect on the performance of $28.57 \%$. While the leadership directly have significant influence on the performance by $2.46 \%$ and indirectly (through the psychological empowerment) amounted to $3.96 \%$ and the effect totaling $12.67 \%$. Limitations of this study is not considering the information about the type of company where respondents worked. Someone who works at the national and international levels company's are assumed to have a different perception of leadership. Future research is also expected to add the variables associated with the impact of psychological empowerment, such as organizational commitment, job satisfaction because these variables is an issue that is always evolving in the management of human resources.

\section{References}

Arslan, O., Gurel, O., \& Kadioglu, M. (2010). A New Tool for Evaluating and Training Of Chemical Tanker Crew: Seafarer Evaluation And Training Software: DEPEDES (SETS). TransNav, International Journal on Marine Navigation and Safety od Sea Transportation, 4(4).

Avolio, B., Bass, B. (1995) Multifactor Leadership Questionnaire includes actual form and ought form and scoring guide, Mind Garden, Inc .

Avolio, B.J., Zhu, W., Koh, W., Bhatia, P. (2004) : Transformational leadership and organizational commitment : mediating role of psychological empowerment and moderating role of structural distance), Journal of Organizational Behaviour 25, 951-968.

Azwar, S. (2007) Metode Penelitian.Yogyakarta:Pustaka Pelajar.

Bandura, A., \& Locke, E. A. (2003). Negative self-efficacy and goal effects revisited. Journal of Applied Psychology, 88, 87-99.

Befort, N., \& Hattrup, K., (2003) Valuing Task and Contextual Performance: Experience, Job Roles, and Ratings of the Importance of Job Behaviors Applied H.R.M. Research, 2003, Volume 8, Number 1, pages 17-32

Bordin, C., \& Bartram, T. (2006). The antecedents and consequences of psychological empowerment among Singaporean IT employees. Management Research News Vol 30 No.1

Budihardjo, A. (2013). Corporate culture in action - Membangun budaya profesional untuk memenangkan persaingan bisnis. Jakarta : Prasetya Mulya Publishing

Chaur-Luh Tsai, Yan-Wei Liou. (2017) Determinants of work performance of seafarers. Maritime Business Review, $2(1)$, pp.36-51

Clarke, S. (2013). Safety leadership: A meta-analytic review of transformational and transactional leadership styles as antecedents of safety behaviours. Journal of Occupational and Organizational Psychology. 86(1) pp 22- 


\section{9}

Delgado, O., García, V., Martínez, X. (2013) MLQ Analysis of leadership in short sea shipping (The human element in short sea shipping operations / Labour considerations)

Fried, Y., \& Ferris, G. R. (1987). The validity of the job characteristics model: A review and meta-analysis. Personnel Psychology, 40(2), 287-322.

Gregory, B.T., \& Osmonbekov, M.D.A.T (2010) The mediating role of psychological empowerment on the relationship between p-o fit, job satisfaction, and in-role performance. J Bus Psychol , 2010, 25, 639-647 Springer Science

Hechanova, M.R., Alampay, R.B.A., Franco, E.P. (2006) Psychological empowerment, job satisfaction and performance among Filipino service workers. Asian Journal of Social Psychology,9,72-78

Humphrey, S.E., Nahrgang, J.D., \& Morgeson, F.P. (2007). Integrating motivational, social, and contextual work design features: A metaanalytic summary and theoretical extension of the work design literature. Journal of Applied Psychology, 92, 1332-1356.

Ikawati \& Damar (2014) : Defisit Pelaut di Negeri Bahari, Jurnal Maritime edisi 10 Februari 2014

Indradevi (2012)., The impact of psychological empowerment on job performance and job satisfaction in indian software companies. EXCEL International Journal of Multidisciplinary Management Studies Vol.2 Issue 4

Joo, B.K. (Brian)., Shim, J.H. (2010) : Psychological empowerment and organizational commitment : the moderating effect of organizational learning culture, Human Resource Development International Vol 13 No 4. $425-441$

Koopmans, L., Bernaards, C.M., Bernaards, V.H., Schaufeli, W.B., Vet, H.C.W., Beek, A.J. (2011) : Conceptual frameworks of individual work performance a systematic review, American College of Occupational and Environmental Medicine, Volume 53, Number 8

Li, K.X., Yin, J., Luo, M. and Wang, J. (2014) 'Leading factors in job satisfaction of Chinese seafarers', Int. J. Shipping and Transport Logistics, Vol. 6, No. 6, pp.680-693.

Liden, R.C., Sparrowe, R.T \& Wayne, S.J. (1997) Leader-member exhange theory : The past and potnestial for the future. In G. Ferris (Ed.) Research in personnel and human resource management (Vol 15, pp 47-119) Greenwich, CT : JAI Press

Nazir, M. (2005) : Metode Penelitian, Bogor : Ghalia Indonesia

Oladipo S.E (2009). Psychological empowerment and development : Edo Journal of Counseling Vol 2 No 1

Pratama, W. (2014) : Model pembelajaran karakter pelaut pada perguruan tinggi kepelautan, Seminar Nasional Pengajar Maritim Indonesia Politeknik Pelayaran Surabaya, 16-17 Oktober 2014

Stajkovic, A. D., \& Luthans, F. (1998). Self-efficacy and work-related performance: A meta-analysis. Psychological Bulletin, 124, 240-261.

Seibert, S.E., Wang, G., Courtright, SH. (2011). Antecedents and consequences of psychological and team empowerment in organization A meta-analytic review : Journal of Applied Psychology Vol 96, No. 5

Solanki, I. (2007). Empowering the seafarer : manpower solution of the shipping industry.: Digital Repository of the World Maritime University World Maritime University Dissertations

Spreitzer, GM. (1995)., Psychological empowerment in the workplace : dimensions, measurement, and validations. Academy of management Journal 1995, Vol 38, No 5, 1442-1465

Spreitzer, G.M. (1996) Social structural characteristics of psychological empowerment. Academy of management Journal 1996, Vol 39, No 2, 483-504.

Spreitzer, G.M., Kizilos, M.A., Nazon, S.W. (1997) A dimensional analysis of the relationship between psychological empowerment and effectiveness, satisfaction, and strain. Journal of Management 1997, Vol 23 N0 5, 679-704

Thomas, K.W., Velthouse, B.A. (1990) Cognitive elements of empowerment: an "interpretive" model of itrinsic task motivation. Academy of Management Review, 15 (4), 666-

Tuuli, M.M., Rowlinson, S. (2009). Performance consequences of psychological empowerment. Journal of Construction Engineering and Management ASCE December 2009

Wu, B., Lai, K. H., \& Cheng, T. E. (2006). Emergence of 'new professionalism'among Chinese seafarers: empirical evidence and policy implications. Maritime Policy \& Management, 33(1), 35-48.

Yukl, G. (2010) Kepemimpinan dalam organisasi edisi kelima, terjemahan Budi Supriyanto, Jakarta : PT Indeks 